\title{
Correlation and Path Coefficient Analysis of Selected Red Tamarind (Tamarindus indica var rhodocarpha) Genetic Resources
}

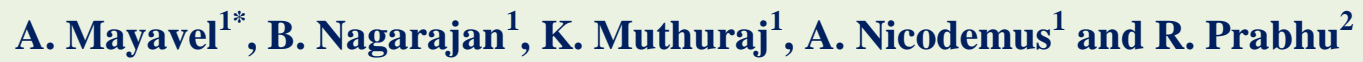 \\ ${ }^{1}$ Institute of Forest Genetics \& Tree Breeding, Forest Campus, Coimbatore - 641002 , \\ Tamil Nadu, India \\ ${ }^{2}$ Centre for Plant Breeding \& Genetics, Tamil Nadu Agricultural University, \\ Coimbatore - 641 003, Tamil Nadu, India \\ *Corresponding author
}

\section{A B S T R A C T}

\begin{tabular}{|c|c|}
\hline $\begin{array}{l}\text { Red tamarind, } \\
\text { Correlation, Path } \\
\text { analysis, Yield, } \\
\text { Quality }\end{array}$ & $\begin{array}{l}\text { Correlation and path coefficient analysis was carried out to identify suitable selection } \\
\text { indices in } 21 \text { red tamarind genotypes for } 15 \text { characters. Correlation analysis revealed that } \\
\text { length of inflorescence }(\mathrm{cm}) \text {, number of flowers/inflorescence, number of } \\
\text { fruits/inflorescence, fruit length }(\mathrm{cm}) \text {, fruit breadth }(\mathrm{cm}) \text {, fruit weight }(\mathrm{g}) \text {, pulp weight }(\mathrm{g}) \\
\text { and anthocyanin content }(\mathrm{mg} / \mathrm{litre}) \text { contributed to a large extent to yield per tree. Hence } \\
\text { these characters could be effectively used in red tamarind improvement programme for }\end{array}$ \\
\hline Article Info & \\
\hline $\begin{array}{l}\text { Accepted: } \\
\text { 07 March } 2018 \\
\text { Available Online: } \\
10 \text { April } 2018\end{array}$ & $\begin{array}{l}\text { anthocyanin content and total sugar contributing directly to the yield and most other } \\
\text { characters associated to fruit yield are contributing indirectly through these characters. } \\
\text { Hence it might be inferred that these traits could be considered as most important yield } \\
\text { contributing traits in red tamarind. }\end{array}$ \\
\hline
\end{tabular}

\section{Introduction}

Tamarind is a diploid species $(2 \mathrm{n}=24)$ (Purseglove, 1987), large evergreen or semievergreen tree growing up to 20 meters in height, sometimes with trunk up to 4.0 meters in width and with a dense spreading crown (Allen and Allen, 1981). The branches are crooked, thick and wide spread thus tamarind has poor tree form (Storrs, 1995). It is a potential multipurpose forest genetic resource, awaiting large-scale domestication. Every part such as wood, roots, leaves, bark and fruits has some value of commerce, particularly in the subsistence of rural people (Gunasena and Hughes, 2000). Tamarind could be a potential tree species in the livelihood of the arid and semi-arid regions (Nagarajan et al., 1998). India is the major exporter of tamarind pulp and seeds with an annual trade worth 2.1 million dollars (Vinning and Moody, 1997). Traditionally, tamarind fruit pulp is used for culinary, flavoring, food preservatives, jelly making, pickle, jams and beverages (Zablocki, 1995). Industrial use of tamarind includes extraction of polysaccharides, starch, tartarates, textile sizing, paper binding, jute weaving, adhesive making, dyeing, tanning, 
mordanting, purifying water and in coagulation of natural rubber (Shankaracharya, 1998). A wide variation could be observed on tree growth, canopy size, flowering pattern, fruit productivity and pulp colour in Tamarind. Based on the pulp colour tamarind is classified as red tamarind and brown tamarind. The red tamarind is taxonomically known as Tamarindus indica var rhodocarpa. This red tamarind is a rare mutant with scattered distribution and availability of this phenotypic variant is not well known in different parts of the country as well as in the world. The fruit colour in unripe stage is red due to presence of anthocyanin.

The content of anthocyanin is high in red tamarind (180 to $360 \mathrm{mg} / \mathrm{g}$ of unripe fruit), while comparing with other anthocyannin rich fruits like grapes $(80-90 \mathrm{mg} / \mathrm{g})$, cherry $(70-75$ $\mathrm{mg} / \mathrm{g}$ ) and jamun (120-130 mg/g). Red tamarind's anthocyanin also has rich antioxidant properties. Hence it will have wide scope for utilizing as potential bio-colorant in food processing, pharmaceutical, brewary and confectionery industries to replace the existing use of carcinogenic inorganic colorants.

Fruit yield is a very complex economic character and outcome of association of number of factors inherent in plant, genetic linkage and the environment in which the plant is grown. In any tree improvement program, it is essential to know the association among yield and yield related traits in the material generated, for effectual selection. Selection based on simply inherited and highly heritable yield attributes is most effective and reliable approach as compared to direct selection on yield itself. Understanding the nature and extent of association of different yield components with yield and inter relationship among themselves is an essential pre requisite for the formulation of breeding procedure for effective improvement of yield (Prabhu et al., 2016).
The correlation and path analysis studies are important in fruit crops like tamarind, mango and citrus, where in quantity and quality traits are important in improvement program. Together it will provide knowledge on interrelationships and relative contribution of independent characters on dependent variable which enables a tree breeder to apply suitable selection procedures in tree improvement program. The knowledge on nature and magnitude of interrelationship among yield and its contributing factor is mandatory for the simultaneous improvement of characters and yield. Hence, an attempt was made in the present study to understand the direction and extent of character association, and the direct and indirect effect of other component traits on yield in red tamarind.

\section{Materials and Methods}

An experiment was conducted to evaluate 21 selected genotypes of red tamarind at Forest Research Station, Institute of Forest Genetics and Tree Breeding, Kurumbapatty, Salem, Tamil Nadu. A well planned survey was conducted for selection of red tamarind germplasm from different parts of Tamil Nadu, Puducherry, Karnataka and Andhra Pradesh for a period of 3 years from 20062008. Detail of red tamarind genotypes used for the present study is presented in Table 1. The selected red tamarind plus trees were multiplied through cleft grafting and planted in random block design (RBD) with 4 replications. Clones were planted in the spacing of $5 \times 5$ meters and 3 ramets/replication were maintained. The field trail was established in 2008 and evaluated during fruiting season of 2014-2016. Observations were recorded in 21 genotypes for 15 characters viz., length of inflorescence $(\mathrm{cm})$, number of flowers/inflorescence, number of fruits/inflorescence, fruit length $(\mathrm{cm})$, fruit breadth $(\mathrm{cm})$, fruit weight $(\mathrm{g})$, pulp weight $(\mathrm{g})$, number of seeds, seed weight $(\mathrm{g})$, anthocyanin 
content (mg/litre), total soluble solids (TSS), total sugar (\%), acidity (\%), ascorbic acid $(\mathrm{mg} / \mathrm{gm})$ and yield/tree (kg). Simple correlation coefficient analysis for yield and yield components were carried out employing the formula propounded by Al-jibouri et al., (1985). Path analysis was adopted to partition the correlation coefficient into direct and indirect effects as suggested by Dewey and $\mathrm{Lu}$ (1959). The path coefficients were ranked on the scales given by Lenka and Misra (1973).

\section{Results and Discussion}

\section{Association analysis}

The aim of correlation studies is primarily to know the suitability of various characters for indirect selection (Prabhu et al., 2015). Correlation studies provide information on the nature and extent of association between any two metric traits and it will be possible to bring about genetic upgradation in one trait by selection of the other of a pair. The association of yield with different quality and yield components in 21 genotypes were estimated and presented in Table 2.

Taking all the 15 characters into consideration, yield/tree $(\mathrm{kg})$ expressed significant and positive relationship with length of inflorescence $(\mathrm{cm})$, number of flowers/inflorescence, number of fruits/inflorescence, fruit length $(\mathrm{cm})$, fruit breadth $(\mathrm{cm})$, fruit weight $(\mathrm{g})$, pulp weight $(\mathrm{g})$ and anthocyanin content ( $\mathrm{mg} /$ litre). Hence it might be inferred that these traits could be considered as most important yield contributing traits in red tamarind. This is in accordance with the findings of Shivanandam and Raju (1988), Prasad et al., (1998), Divakara et al., (2008) and Singh and Nandhini (2014).

Number of flowers/inflorescence recorded significant and positive correlation with length of inflorescence $(\mathrm{cm})$ in all the 21 genotypes taken for the study. These findings were also reported earlier by Prasad et al., (1998) and Divakara et al., (2008). All the 21 genotypes expressed significant and positive association with length of inflorescence $(\mathrm{cm})$ and number of flowers/inflorescence for number of fruits/inflorescence. Similar results were reported by Challapillai et al., (1995).

The character fruit length $(\mathrm{cm})$ exhibited significant and positive correlation with length of inflorescence $(\mathrm{cm})$, number of flowers/inflorescence and number of fruits/inflorescence in all the 21 genotypes. Shivanandam and Raju (1988), Prasad et al., (1998), Divakara et al., (2008) and Singh and Nandhini (2014) also observed similar associations with one or more characters for the trait fruit length $(\mathrm{cm})$. Fruit breadth $(\mathrm{cm})$ possessed significant and positive association with length of inflorescence $(\mathrm{cm})$, number of flowers/inflorescence, number of fruits/inflorescence and fruit length $(\mathrm{cm})$. These results are confirmative with findings of Shivanandam and Raju (1988) and Singh and Nandhini (2014).

The character fruit weight (g) exhibited significant and positive association with length of inflorescence $(\mathrm{cm})$, number of flowers/inflorescence, number of fruits/inflorescence, fruit length $(\mathrm{cm})$ and fruit breadth $(\mathrm{cm})$ in all the 21 genotypes.

Challapilli et al., (1995) and Divakara et al., (2008) reported that the fruit weight is positively and significantly associated with pulp, fibre, seed weight, fruit length and breadth. All the 21 genotypes expressed significant and positive association with fruit length $(\mathrm{cm})$, fruit breadth $(\mathrm{cm})$ and fruit weight (g) for pulp weight (g). Prasad et al., (1998), Divakara et al., (2008) and Singh and Nandhini (2014) were also reported similar results. 
Table.1 Geographic position of selected red tamarind genetic resources

\begin{tabular}{|c|c|c|c|c|c|}
\hline S. No. & Tree Code & Tree name & \multicolumn{2}{|c|}{ GPS Position } & Elevation \\
\hline 1 & TVTVR-1 & Vengalapuram Red - 1 & N $11^{\circ} 45.140^{\prime}$ & E $78^{\circ} 09.417^{\prime}$ & 367 \\
\hline 2 & TTCER-1 & Eraiyur Red - 1 & N $12^{\circ} 06.186^{\prime}$ & E $78^{\circ} 54.464^{\prime}$ & 369 \\
\hline 3 & TVAMR-1 & Machempattu Red - 1 & N 1251.479' & E 7842.390' & 360 \\
\hline 4 & TVGPR-1 & Peranampet Red - 1 & N 12⒌67. & E $78^{\circ} 42.916^{\prime}$ & 358 \\
\hline 5 & TDNNR-1 & Natham Red - 1 & N $10^{\circ} 18.241^{\prime}$ & E $78^{\circ} 03.677^{\prime}$ & 348 \\
\hline 6 & TTPJR-1 & Jayamangalam Red - 1 & N $10^{\circ} 06.164^{\prime}$ & E $77^{\circ} 36.182^{\prime}$ & 352 \\
\hline 7 & TTPJR-2 & Jayamangalam Red - 2 & N $10^{\circ} 06.164^{\prime}$ & E $77^{\circ} 36.181^{\prime}$ & 272 \\
\hline 8 & TTPJR-3 & Jayamangalam Red - 3 & N $10^{\circ} 06.176^{\prime}$ & E $77^{\circ} 36.176^{\prime}$ & 272 \\
\hline 9 & TTPPR-4 & Podi Red - 4 & $\mathrm{~N} 10^{\circ} 01.249^{\prime}$ & E $77^{\circ} 20.341^{\prime}$ & 349 \\
\hline 10 & TVRRR-1 & Rajapalayam Red - 1 & N $10^{\circ} 06.164^{\prime}$ & E $77^{\circ} 36.182^{\prime}$ & 352 \\
\hline 11 & TVGSR-4 & Shivaraj Nager Red - 4 & N $12^{\circ} 56.048^{\prime}$ & E $78^{\circ} 42.243^{\prime}$ & 364 \\
\hline 12 & TKUNR-1 & Nelluvai Red - 1 & $\mathrm{~N} 11^{\circ} 00.885^{\prime}$ & E $76^{\circ} 56.655^{\prime}$ & 419 \\
\hline 13 & TVAKR-1 & Kedampur Red - 1 & N $12^{\circ} 50.248^{\prime}$ & E $78^{\circ} 42.548^{\prime}$ & 413 \\
\hline 14 & TMPKR-1 & Kuvalapuram Red - 1 & N 0941.091' & E $77^{\circ} 45.504^{\prime}$ & 389 \\
\hline 15 & TCPPR-1 & Pollachi Red - 1 & $\mathrm{~N} 10^{\circ} 44^{\prime} 52.85^{\prime \prime}$ & $\mathrm{E} 77^{\circ} 6^{\prime} 0.73^{\prime \prime}$ & 354 \\
\hline 16 & PKKKR-1 & Karaikal Red - 1 & N 1057.013' & E 7946.519' & 3 \\
\hline 17 & PKKKR-2 & Karaikal Red - 2 & N 1056.992' & E $79^{\circ} 46.519^{\prime}$ & 3 \\
\hline 18 & AHHMR-1 & Meduk Red - 1 & N18 $3^{\prime} 11.78^{\prime \prime}$ & E78 $16 ' 2.42^{\prime \prime}$ & 467 \\
\hline 19 & AHHMR-2 & Meduk Red - 2 & N183'13.28" & E78 $16^{\prime} 3.26^{\prime \prime}$ & 468 \\
\hline 20 & KKPCR-1 & Chittampalli Red - 1 & $\mathrm{~N} 13^{\circ} 0^{\prime} 32.89^{\prime \prime}$ & E78 29' 28.74" & 725 \\
\hline 21 & KCKKR-1 & Kadur Red - 1 & N133' 11.02" & E76 ${ }^{\circ} 0 ' 52.57 "$ & 773 \\
\hline
\end{tabular}


Table.2 Simple correlation coefficient matrix for yield and quality traits in red tamarind

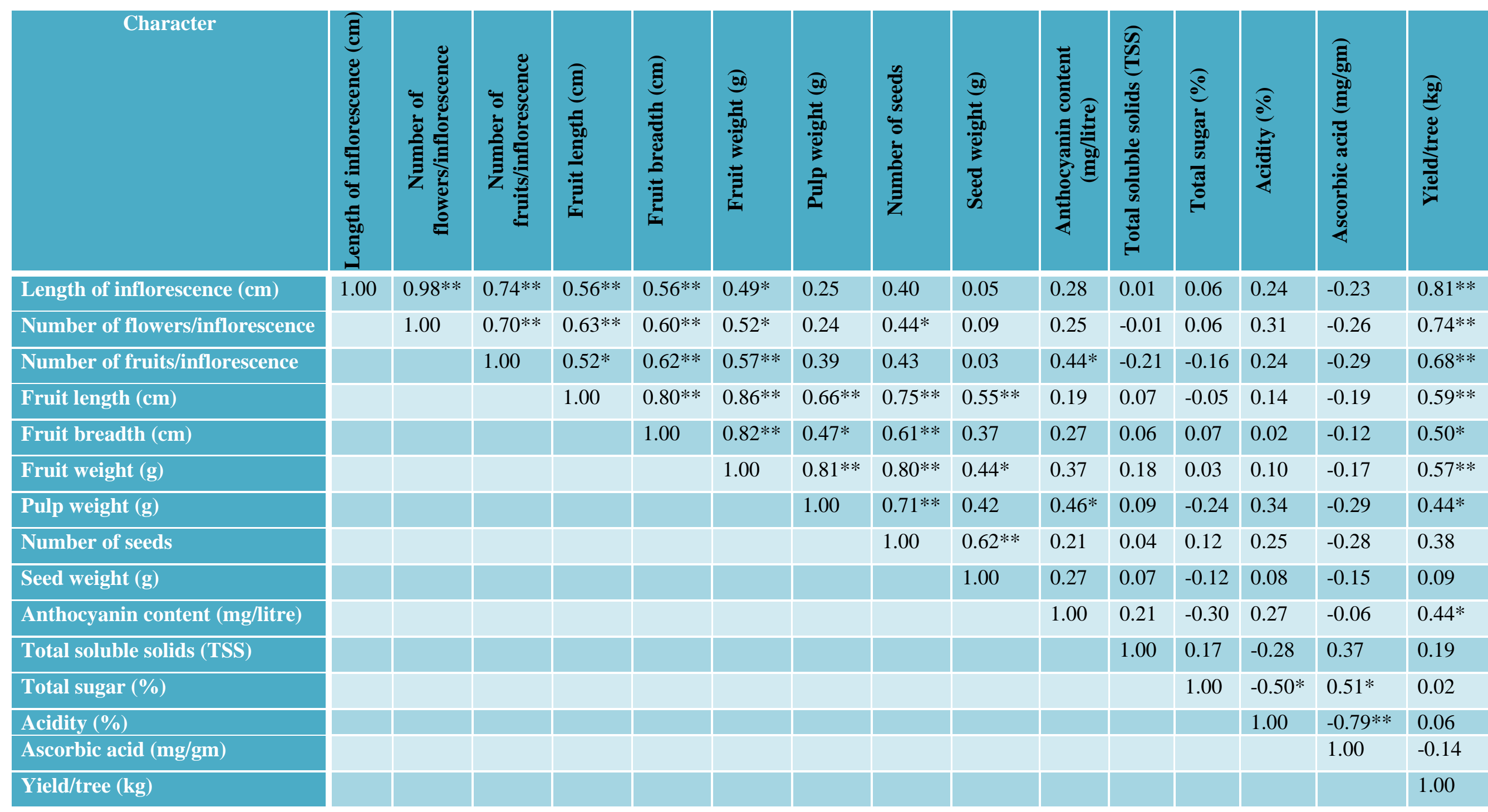

*, ** Significant at $\mathrm{P}=0.05$ and $\mathrm{P}=0.01$ level of probability, respectively 
Table.3 Direct and indirect effects of different quantitative and qualitative characters on yield of red tamarind

\begin{tabular}{|c|c|c|c|c|c|c|c|c|c|c|c|c|c|c|c|}
\hline Character & 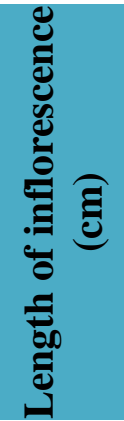 & 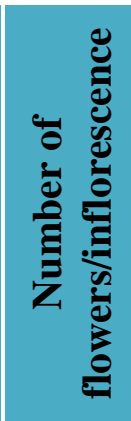 & 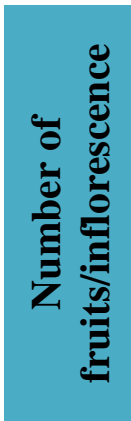 & 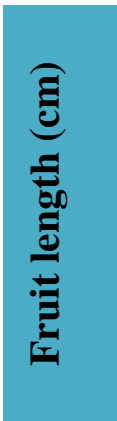 & 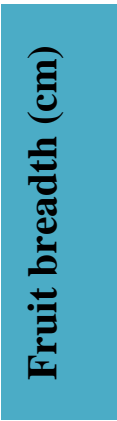 & 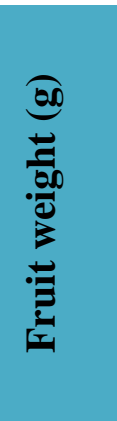 & 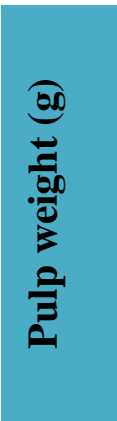 & 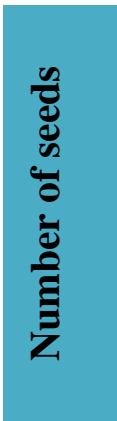 & 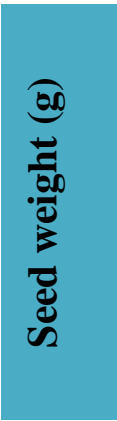 & 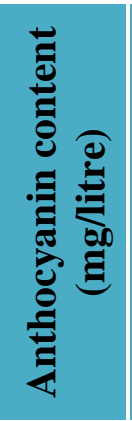 & $\begin{array}{l}\frac{0}{3} \\
\frac{0}{0} \\
\frac{0}{0} \\
\frac{0}{3} \\
\frac{0}{8} \\
\frac{\pi}{E} \\
\frac{\pi}{0}\end{array}$ & 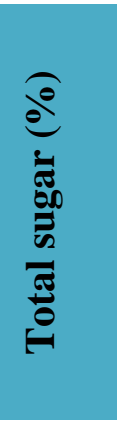 & $\frac{\widehat{\theta}}{\stackrel{0}{0}}$ & 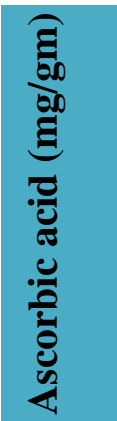 & 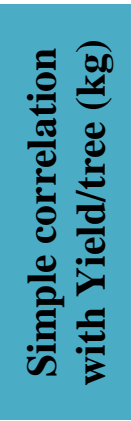 \\
\hline Length of inflorescence (cm) & 2.18 & -1.86 & -0.11 & 0.74 & -0.18 & -0.12 & -0.04 & -0.02 & -0.01 & 0.15 & -0.01 & -0.01 & -0.05 & 0.15 & $0.81 * *$ \\
\hline $\begin{array}{l}\text { Number of } \\
\text { flowers/inflorescence }\end{array}$ & 2.12 & -1.91 & -0.10 & 0.83 & -0.19 & -0.13 & -0.04 & -0.02 & -0.03 & 0.13 & -0.01 & -0.01 & -0.07 & 0.16 & $0.74 * *$ \\
\hline $\begin{array}{l}\text { Number of } \\
\text { fruits/inflorescence }\end{array}$ & 1.60 & -1.32 & -0.15 & 0.68 & -0.20 & -0.14 & -0.07 & -0.02 & 0.00 & 0.25 & -0.03 & -0.09 & -0.04 & 0.21 & $0.68 * *$ \\
\hline Fruit length (cm) & 1.18 & -1.18 & -0.07 & 1.35 & -0.26 & -0.21 & -0.12 & -0.03 & -0.23 & 0.09 & -0.01 & -0.05 & -0.02 & 0.14 & $0.59 * *$ \\
\hline Fruit breadth (cm) & 1.19 & -1.13 & -0.09 & 1.07 & -0.32 & -0.20 & -0.08 & -0.03 & -0.15 & 0.14 & -0.01 & -0.01 & 0.01 & 0.11 & $0.50 *$ \\
\hline Fruit weight (g) & 1.04 & -0.97 & -0.08 & 1.16 & -0.26 & -0.25 & -0.15 & -0.04 & -0.18 & 0.21 & 0.00 & -0.02 & -0.01 & 0.12 & $0.57 * *$ \\
\hline Pulp weight (g) & 0.49 & -0.42 & -0.05 & 0.88 & -0.15 & -0.20 & -0.18 & -0.03 & -0.18 & 0.27 & -0.01 & -0.09 & -0.07 & 0.18 & $0.44^{*}$ \\
\hline Number of seeds & 0.82 & -0.80 & -0.06 & 1.00 & -0.19 & -0.20 & -0.13 & -0.05 & -0.26 & 0.09 & -0.01 & -0.01 & -0.05 & 0.20 & 0.38 \\
\hline Seed weight (g) & 0.06 & -0.15 & 0.00 & 0.73 & -0.12 & -0.11 & -0.08 & -0.03 & -0.43 & 0.15 & 0.00 & -0.05 & -0.01 & 0.10 & 0.09 \\
\hline $\begin{array}{l}\text { Anthocyanin content } \\
\text { (mg/litre) }\end{array}$ & 0.53 & -0.42 & -0.06 & 0.20 & -0.08 & -0.09 & -0.08 & -0.01 & -0.11 & 0.61 & -0.01 & -0.13 & -0.05 & 0.10 & $0.44^{*}$ \\
\hline Total soluble solids (TSS) & -0.60 & 0.58 & 0.11 & -0.30 & 0.07 & 0.01 & 0.03 & 0.02 & 0.04 & -0.10 & -0.03 & -0.23 & 0.21 & 0.25 & 0.19 \\
\hline Total sugar $(\%)$ & -0.14 & 0.13 & 0.07 & -0.31 & 0.02 & 0.03 & 0.08 & 0.00 & 0.11 & -0.40 & -0.04 & 0.20 & 0.22 & -0.06 & 0.02 \\
\hline Acidity (\%) & 0.44 & -0.53 & -0.03 & 0.13 & 0.01 & -0.01 & -0.06 & -0.01 & -0.02 & 0.13 & -0.03 & -0.19 & -0.24 & 0.44 & 0.06 \\
\hline Ascorbic acid (mg/gm) & -0.96 & 0.91 & 0.09 & -0.54 & 0.10 & 0.09 & 0.10 & 0.03 & 0.12 & -0.18 & -0.03 & 0.03 & 0.31 & -0.34 & -0.14 \\
\hline
\end{tabular}

Residual effects: 0.219; Bold figures denote direct effect; *, ** Significant at $\mathrm{P}=0.05$ and $\mathrm{P}=0.01$ level of probability, respectively 
Among the 15 characters studied, number of seeds recorded significant and positive correlation with number of flowers/inflorescence, fruit length $(\mathrm{cm})$, fruit breadth $(\mathrm{cm})$, fruit weight $(\mathrm{g})$ and pulp weight $(\mathrm{g})$ in the all the 21 genotypes of red tamarind. These results are confirmative with findings of Singh and Nandhini (2014). Seed weight $(\mathrm{g})$ possessed significant and positive correlation with fruit length $(\mathrm{cm})$, fruit weight (g) and number of seeds in all the 21 genotypes taken for the study. These findings were also reported earlier by Samiullah et al., (1993).

The character anthocyanin content (mg/litre) exhibited significant and positive correlation with number of fruits/inflorescence and pulp weight $(\mathrm{g})$. In all the 21 genotypes, the traits total soluble solids (TSS) and total sugar (\%) does not show significant/association with any of the remaining traits studied. Ascorbic acid (mg/gm) recorded significant and positive correlation with total sugar (\%) whereas; it expressed significant and negative association with acidity (\%). However, the character acidity (\%) expressed significant and negative association with total sugar (\%). Kaiser and Hulmani (1993), Abilash et al., (2016) in guava, Chakrawar and Jathure (1980) in lime, Saha (2004) in lemon and Krishna et al., (2017) in mango also observed similar associations with one or more characters experimented.

\section{Path analysis}

Path analysis is a form of multiple regression statistical analysis used to evaluate causal models by examining the relationships between a dependent variable and two or more independent variables. The results on direct and indirect effects of different quantitative and qualitative traits on fruit yield are presented in Table 3. The estimated residual effect is 0.219 indicating that $80 \%$ of the variability in fruit yield was contributed by the quantitative and qualitative characters studied in the path analysis.

Path coefficient analysis revealed that, the length of inflorescence (2.18) is the most pronounced character contributing directly to the yield followed by fruit length (1.35), anthocyanin content $(0.61)$ and total sugar (0.20). Therefore, direct selection of these traits could be useful in red tamarind improvement programme. While the number of flowers/inflorescence recorded negative direct effects (-1.91). Hence, such character should never consider as a parameter in selection programmes. Most other characters associated to fruit yield are contributing indirectly through above characters. Similar findings were reported by Kulkarni et al., (1995), Prasad et al., (1998), Divakara et al., (2008) and Singh and Nandhini (2014).

Tamarind fruit pulp is an important economic trait which governs with several qualitative and quantitative attributes. The results of correlation coefficient analysis revealed that length of inflorescence $(\mathrm{cm})$, number of flowers/inflorescence, number of fruits/inflorescence, fruit length $(\mathrm{cm})$, fruit breadth $(\mathrm{cm})$, fruit weight $(\mathrm{g})$, pulp weight $(\mathrm{g})$ and anthocyanin content (mg/litre) attributes contributed to a large extent to yield per tree. Hence these characters could be effectively used in tamarind improvement programme for selecting genotypes with higher yield and quality as they show positive and significant association. However in path coefficient analysis, the length of inflorescence is the most pronounced character contributing directly to the yield followed by fruit length, anthocyanin content and total sugar, and most other characters associated to fruit yield are contributing indirectly through these characters. Hence it might be inferred that this trait could be considered as most important yield contributing trait in red tamarind. 


\section{References}

Abhilash, L., Suresh kumar, T., Raja goud, C.H., Girwani, A. and Narendar reddy, S. 2016. Correlation studies in fruit characters of guava (Psidium guajava L.) cv. Lucknow - 49, Advances in Life sciences, 5(17): 6924-6926.

Al-jibouri, H.A., Miller, P.A. and Robinson, H.P. 1985. Genotypic and environmental variances and covariances in upland cotton cross of interspecific origin. Agronomy Journal, 50: 633-636.

Allen, O.N. and Allen, E.K. 1981. The Leguminosae: A source book of characteristics, uses and nodulation. W.S. Madison (Ed.), University of Wisconsin Press, pp 812.

Chakrawar, V.R. and Jathure, S.D. 1980. Correlation studies on Kagzi lime strains, Punjab Horticultural Journal, 20: 39-40.

Challapilli, A.P., Chimmad, V.P. and Hulamini, N.C. 1995. Studies on correlation of some fruit characters in tamarind fruits. Karnataka Journal of Agricultural Science, 8(1): 114-115.

Dewey, D.R. and Lu, K. 1959. A correlation and path-coefficient analysis of components of crested wheatgrass seed production. Agronomy Journal, 51(9): 515-518.

Divakara, B.N. 2008. Variation and character association for various pod traits in Tamarindus indica L. Indian Forest, 134(5): 687-696.

Gunasena, H.P.M. and Hughes, A. 2000. Tamarind (Tamarindus indica L.). International Centre for underutilized crops, University of Southampton, ISBN 084532724, United Kingdom.

Kaiser, M. and Hulmani, N.C. 1993. Correlation studies in fruit characters of guava (Psidium guajava L.) Navalur
Selections. Karnataka journal of Agricultural sciences, 6(4): 345-347.

Krishna, V.G., Bhagwan, A., Kumar, K.A. and Girwani, A. 2017. Correlation studies in yield and yield attributes of mango (Mangifera indica L.) cv. Banganpalli, International Journal of Pure and Applied Biosciences, 5(4): 976-979.

Kulkarni, R.S., Kumar, B.M.K., Swamy, G.S.K., Gangaprasad, S. and Dushyanthakumar, B.M. 1995. Path analysis of pulp yield in tamarind (Tamarindus indica) across provenances of Karnataka. Journal of Non-Timber Forest Product, 2(3-4): 157-159.

Lenka, D. and Misra, B. 1973. Pathcoefficient analysis of yield in rice varieties. Indian Journal of Agricultural Sciences, 43(4): 376-379.

Nagarajan, B., Nicodemus, A., Mandal, A.K., Verma, R.K. and Mahadevan, N.P. 1998. Phenology and controlled pollination studies in tamarind. Silvae Genetica, 47(5-6): 237-241.

Prabhu, R., Manivannan, N., Mothilal, A. and Ibrahim, S.M. 2015. Correlation coefficient analysis for yield and yield attributes in groundnut (Arachis hypogaea L.). Plant Archives, 15(2): 685689.

Prabhu, R., Manivannan, N., Mothilal, A. and Ibrahim, S.M. 2016. Studies on characters association for yield and its components in groundnut (Arachis hypogaea L.). Current Advances in Agricultural Sciences, 8(1): 49-54.

Prasad, S.G., Nagaraj, T., Kulkarni, R.S. and Swamy, G.S.K. 1998. Correlation and path analysis in Tamarind (Tamarindus indica. L.) across two diverse provinces of southern Karnataka. Journal of Agricultural Science, 11(1): 227-229. 
Purseglove, J.W. 1987. Tropical Crops. Dicotyledons, Longman Science and Technology: 204-206.

Saha, P. 2004. Performance of some lemon germplasm and their morphological and molecular characterization using isozyme, M.Sc. Thesis. Department of Plant Breeding and Genetics, Bangladesh Agricultural University, Mymensingh, Bangladesh. PP 119.

Samiullah, R., Sheriff, R.A. and Chickadevaiah. 1993. Character association and path analysis in tamarind, Abstract of Golden Jubilee symposium on Horticulture Research Changing Scenario, Horticultural society of India, New Delhi, pp 473.

Shankaracharya, N.B. 1998. Tamarind chemistry, technology and uses - A critical appraisal. Journal of Food Technology, 35(3): 193-208.

Shivanandam, V.N. and Raju, K.R.T. 1988. Correlation between some fruit characters of four tamarind (Tamarindus indica L.) types. Mysore Journal of Agricultural Sciences, 22(2): 229-231.

Singh, T.R. and Nandini, R. 2014. Genetic variability, character association and path analysis in tamarind (Tamarindus indica L.) population of Nallur Tamarind Grove. SAARC Journal of Agriculture, 12(1): 20-25.

Storrs, A.E.G. 1995. Know Your Trees. Some common trees found in Zambia. Regional Soil Conservation Unit (RSCU).

Vinning, G. and Moody, T. 1997. A market compendium of tropical fruits. Rural Industries Research and Development Corporation. Canberra, Australia, pp 258-266.

Zablocki, L.P. 1995. Beverages using tamarind extract and method of making such beverages. US Patent No. 547791, Nutrasweet Co. Deerfield, IL, USA.

\section{How to cite this article:}

Mayavel, A., B. Nagarajan, K. Muthuraj, A. Nicodemus and Prabhu, R. 2018. Correlation and Path Coefficient Analysis of Selected Red Tamarind (Tamarindus indica var rhodocarpha) Genetic Resources. Int.J.Curr.Microbiol.App.Sci. 7(04): 794-802. doi: https://doi.org/10.20546/ijcmas.2018.704.089 